\title{
Characterizing Seismo-stratigraphic and Structural Framework of Late Cretaceous-Recent succession of offshore Indus Pakistan
}

https://doi.org/10.1515/geo-2018-0014

Received December 18, 2017; accepted April 29, 2018

Abstract: Regional seismic reflection profiles and deep exploratory wells have been used to characterize the subsurface structural trends and seismo-stratigraphic architecture of the sedimentary successions in offshore Indus Pakistan. To improve the data quality, we have reprocessed the seismic data by applying signal processing scheme to enhance the reflection continuity for obtaining better results. Synthetic seismograms have been used to identify and tie the seismic reflections to the well data. The seismic data revealed tectonically controlled, distinct episodes of normal faulting representing rifting during Mesozoic and transpression at Late Eocene time. A SW-NE oriented anticlinal type push up structure is observed resulted from the basement reactivation and recent transpression along Indian Plate margin. The structural growth of this particular pushup geometry was computed. Six mappable seismic sequences have been identified on seismic records. In general, geological formations are at shallow depths towards northwest due to basement blocks uplift. A paleoshelf is also identified on seismic records overlain by Cretaceous sediments, which is indicative of Indian-African Plates rifting at Jurassic time. The seismic interpretation reveals that the structural styles and stratigraphy of the region were significantly affected by the northward drift of the Indian Plate, post-rifting, and sedimentation along its western margin during Middle Cenozoic. A considerable structural growth along the push up geometry indicates present day transpression in the margin sediments. The present comprehensive interpretation can help in understanding the complex structures in passive continental margins worldwide that display similar characteristics but are considered to be dominated by rifting and drifting tectonics.

Keywords: Seismic sequences, stratigraphy, seismic interpretation, offshore Indus Basin Pakistan, passive continental margins, structural analysis

`Corresponding Author: Majid Khan: Institute of Geology and

\section{Introduction}

The offshore Indus Pakistan offers an excellent view of the progression of Mesozoic and recent tectonic changes concerning the Indian Plate, as it is lying at the triple junction (India, Eurasian, and Arabian Plates). The study of the subsurface structural trends and tectonic setting of the offshore Indus is very important for understanding the impact of the regional geodynamics on stratigraphy and subsurface structures in the region as well as surrounding areas associated with Indian-Arabian Plates. The offshore Indus situated in the southwest of Pakistan (Fig. 1) is an Atlantic type passive continental margin underlain partly by the continuation of the continental crust of the onshore Indus Basin, and partly by the oceanic crust of the Arabian Sea [1]. The Murray Ridge forms the western extremity of the basin, and is extended towards the western coastline of the Indo-Pakistan subcontinent (Fig. 1). The evolution of offshore Indus basin dates back to the rifting of IndoPakistan subcontinent during the Cretaceous- Paleocene age and continues northward drift of the Indian Plate. The collision of the Indian Plate with the Eurasian Plate, which was commenced during the early Cenozoic Era (probably Late Eocene) is responsible for some of the most significant relief in the region [2]. The Seismic data from the Pakistan margin and Owen Fracture Zone (OFZ) reveals that Indus fan sedimentation produced by plate's collision dates back to the mid-Eocene time [3, 4]. The Carlsberg Ridge extends northwest and terminates into the OFZ [5], along this ridge new oceanic crust of the Indian Ocean is forming. The Chaman Fault System is a major continental plate boundary separating the Indian and Eurasian Plates. According

and University of Chinese Academy of Sciences, 100049, Beijing, China, E-mail: majid.khan@mail.iggcas.ac.cn

ORCID: 0000-0001-8516-4466

Yike Liu: Institute of Geology and Geophysics, Chinese Academy of Sciences, Beijing, 100029, China, E-mail: ykliu@mail.iggcas.ac.cn Asam Farid: Onshore Geophysics, Fugro Middle East, Abu Dhabi, 4447, United Arab Emirates, E-mail: asam.farid@gmail.com Muhammad Owais: Exploration Department (Prospect Generation), Oil and Gas Development Company Limited, Islamabad, 44000, Pakistan, E-mail: owais241@gmail.com 
to [6], "the Chaman fault system probably developed since at least 20-25 My and is one of the world's major terrestrial transform faults. The eastern margin of the study area is bounded by Bombay/Mumbai offshore basin which is a divergent passive continental margin, and is located on the continental shelf off the west coast of India [7].

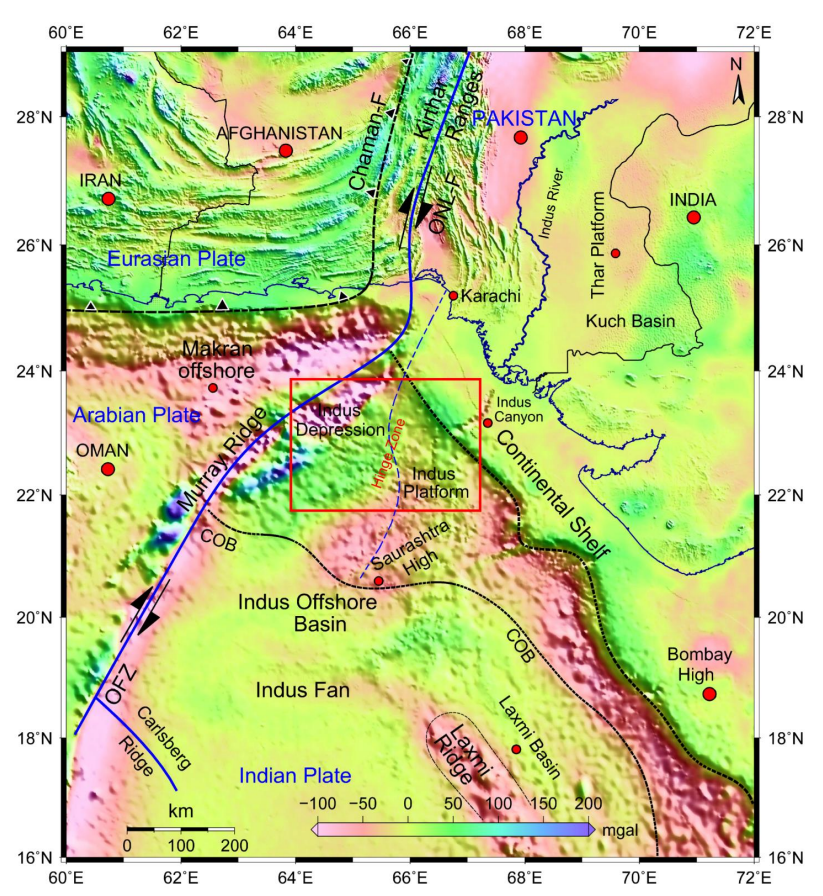

Figure 1: Location Map of Offshore Indus Pakistan and adjacent areas showing topography and free-air satellite gravity. Major tectonic elements are annotated. The study area is highlighted by Red colored triangle. The narrow black line shows political boundaries and shoreline by dotted black color.

Several studies have been carried out in the vicinity of the Indian Plate western margin, most of the earlier works done in the region revolve around the break up history of the Gondwanaland and tectonic evolution of the Indian Ocean [8-12]. [13], and [14] have identified some of the structural features and potential areas for carrying out future exploration activities in the offshore Indus. [15] suggested a seismic facies model of the Indus fan, and described its hydrocarbon potential. [16] carried out study on canyon development and delineated two different phases of canyon development including early Miocene and Plio-Pleistocene. [17] reported the "deposition of the shallow water carbonates along a chain of northeast-southwest trending volcanic seamounts during the time of Paleocene-Eocene. Major clastic input from Indus River led to the deposition of up to $9 \mathrm{~km}$ thick Oligocene to Recent sediments in the study area" [18-
20]. [21] carried out study related to interpretation of volcanic structure and subsidence analysis of the West Indian Continental Margin by using 2D seismic and gravity data. The seismic interpretation becomes challenging when genetic reflections behavior is complex to identify seismic stratigraphic units. The detailed stratigraphic architecture (Cretaceous-Recent) and subsurface structure of the study area is still not well explained by the previous researchers, which possess key importance for vindicating new hydrocarbon exploration targets.

Considering the current research gaps, in this study we have investigated the tectonic, seismo-stratigraphic and structural evolution of the Meso-Cenozoic succession using seismic data tied to well controls from offshore Indus Pakistan. The region has gone through long journey of extensional-transtensional tectonics, thus the study has significant outcomes in understanding the tectonostratigraphy which directly possess economic importance. This study will also be helpful in understanding the impact of India-Eurasian-Arabian Plates tectonic interaction on surrounding regions and can be extended to passive continental margins worldwide.

\section{Regional Geological Setting}

The tectonic evolution of the Indian plate from its original location in Gondwana supercontinent during Permian through Middle Jurassic time, its sequential separation from other Gondwana continents, its continual disintegration, its northward movement as an island continent, and its successive collision, first with the Kohistan-Ladakh Arc followed by with Asia, represents one of the longest journeys of all other continents, about $9000 \mathrm{~km}$ from Gondwana in 160 Mys [22-25]. East Gondwana (including India and some other blocks) separated from Africa in MidJurassic [26-28]. The continental breakup and dispersal of Gondwana is marked by a series of mantle plumes [29]. The offshore Indus Basin is a passive continental margin which was developed following the separation of the Indian Plate from Africa in the late Jurassic [30]. During the Cretaceous, Madagascar separated from India and was followed by the rapid northward movement. In the early Paleocene time, the Indian Plate passed over the Reunion mantle hotspot and hence separation of Seychelles took place with the spreading of the Carlsberg Ridge (Fig. 1). During Eocene, the collision between Indian and Eurasian plate commenced which is shown by the presence of Middle Eocene sandstones in the distal Indus Fan deposits, mainly containing feldspar grains with an origin in, or the 
north of, the Indus Suture zone [3]. Regional unconformities separate the mega sequences which establish a common history of the region before Late Miocene time [31]. The central part of the basin exhibits post-rift down warping and thick sedimentation after the initial separation of continental fragments. The seismic data across the western margin of the basin shows complex structures with some evidence of extensional tectonics probably bounded by normal faults with an expression of a Ridge structure at the central part of the region [1].

During the early post-rift phase, the attached carbonate platforms of Late Paleocene and Early Eocene formed along the continental margin and detached platforms (carbonate banks) on volcanic seamount within the basin [17] shown in Fig. 3. The uplifting of the High Himalayas started in Early Miocene time, plate re-organization during the Early Miocene time resulted in stresses that form the transform margin of the Indian and Arabian Plates which caused Murray Ridge to uplift [18, 19]. In the Oligocene time, the basin initially filled from the north with sediments rapidly prograding southwards. By the Late Miocene time, sediments prograding along a wider front adopted a southwesterly direction with an increasing sediment contribution from the Karachi Platform.

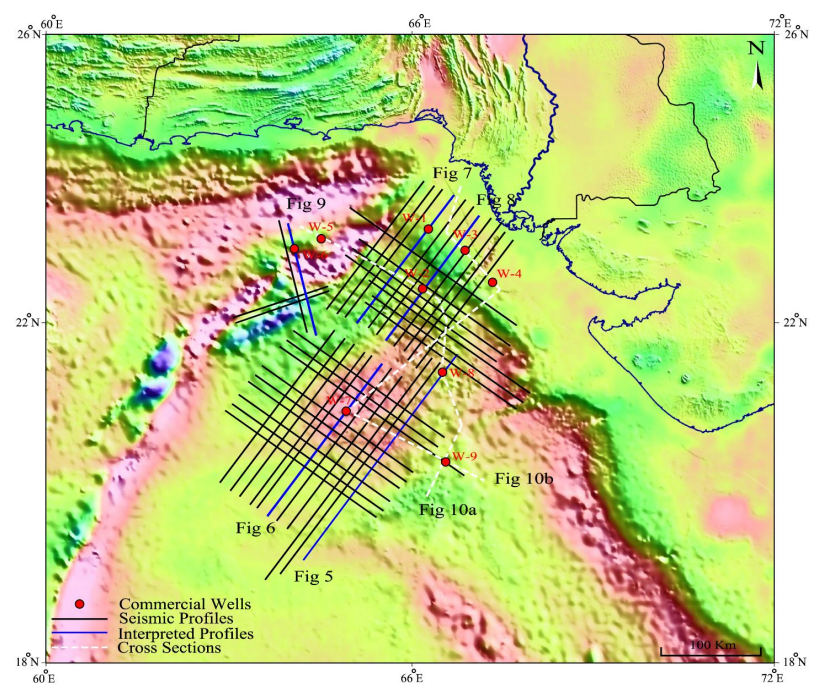

Figure 2: The basemap of the study area with seismic lines and wells location. The blue colored seismic profiles are interpreted and presented in the current study with wells in red color and wells correlation cross section in white color.

The wells drilled in the study area (both shelf and offshore) reaches maximum to Cretaceous aged rock formations. The detail stratigraphy of the study area is represented in (Fig. 3) with correlation of regional tectonic

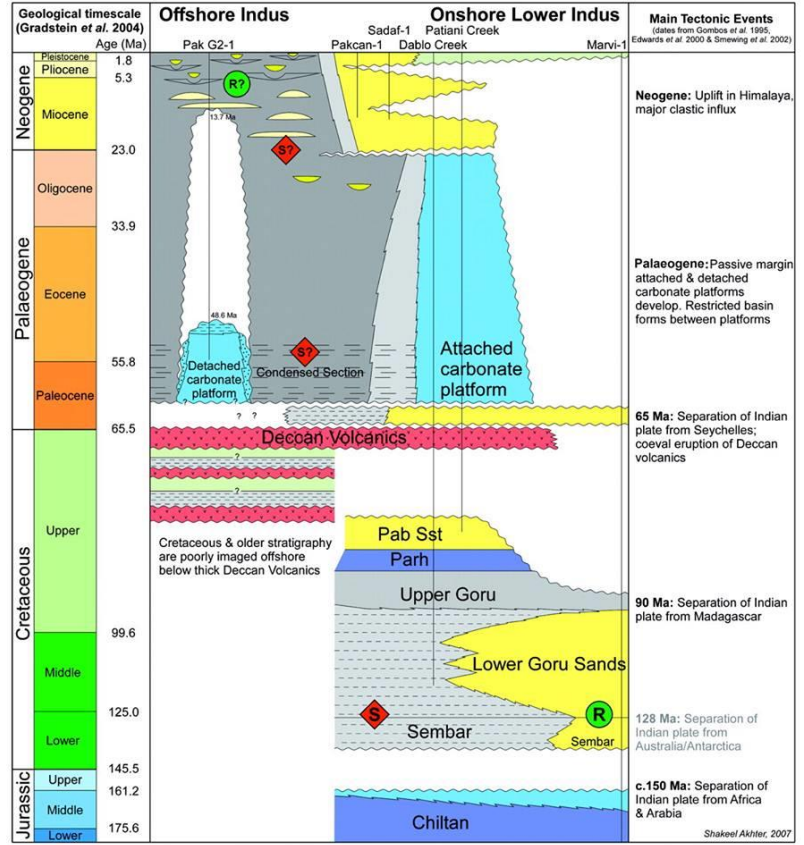

Figure 3: The stratigraphy of the offshore Indus Basin and its correlation with onshore Lower Indus Basin. The right side column shows the Major tectonic events occurred in and around the study area (Gombos et al., 1995; Edwards et al., 2000; Smewing et al., 2002; Akhter, 2007).

events. The Karachi trough is an embayment opening up into the Arabian Sea (Fig. 1) which is characterized by thick Early Cretaceous sediments and also marks the last stage of marine sedimentation [14]. The most interesting feature of Karachi trough is the reportedly continued deposition across the Cretaceous/Tertiary $(\mathrm{K} / \mathrm{T})$ boundary, wherein shales were deposited, this probably represents no hiatus in sedimentation occurred at the end of Cretaceous era. The Kirthar Foredeep which trends in north-south direction of the study area has received the sediments thickness aggregating over $15 \mathrm{~km}$. It has a faulted eastern boundary with Thar Platform. The sediments deposited in this depression appears to be Paleocene aged. The Murray Ridge consists of the crust upto $20 \mathrm{~km}$ thick of uncertain origin [21]. The north of Murray Ridge, the Makran accretionary wedge, developed in response to subduction of the Gulf of Oman oceanic crust beneath Eurasia from about 14 Ma onwards [32]. The Offshore Platform is a westward extension of the Thar Platform, a thick Mesozoic to Cenozoic sediments sequence comprising carbonates and clastic exists in this region. Carbonates deposited on shelf (Ghazij Formation) ranging from Mid-Eocene to Oligocene ages dominate the offshore Indus Delta $[18,19]$. These formations are equivalent to the onshore Laki, Kirthar and Nari formations [16]. Mughal Kot formation (Late Creta- 
ceous) have been encountered in deep wells such as W-4 and W-3 in the Indus Delta [16]. The offshore Indus Basin and the Karachi platform are characterized by thick MidLate Miocene interbedded sand and shales (Gaj Formation), which are interpreted as being shallow water shelf or deltaic deposits [16]. These Mid-Late Miocene deposits are overlain by Pliocene aged or younger muddy shelf which has been successively cut by extensive canyon phases of the proto-Indus [16]. The northward drift of the Indian plate was accompanied by the major clastic influx from the Indus River leading to the deposition of Oligocene to Recent sediments [17].

\section{Dataset and Methods}

The offshore Indus is a high risk, high cost frontier area having no commercial discovery to-date. A total of 16 wells have been drilled and, all were plugged and abandoned due to high pressures. The exploration history started in 1963 to test hydrocarbon potential of the area (minor gas shows). The last well was drilled in 2010 to test Miocene Sands. The present study was conducted by using seven regional seismic migrated sections and data of nine wells with geophysical logs, formation tops and checkshot data. Table 1 shows the information of the well data used. The wells W-1, W-3, W-4 and W-5 are located on shelf whereas W-2, W-6, W-7, W-8 and W-9 are drilled on offshore deep. The seismic lines were chosen in dipping direction in order to image the regional structure and stratigraphic architecture of the study area (location of lines is shown in Fig. 2). The seismic reflections were identified as key horizons by correlating with synthetic seismogram. The reflection quality of these seismic sections is generally not very good. The reflections are more continuous in some parts while discontinuous in other parts, parallel in character having good reflection strength and expected stratigraphic details.

\subsection{Post Stack Signal Processing}

Noise that remains in the post stacked data can have adverse effects on reflection continuity. The signal processing of post stacked seismic data is useful in identifying geological structures, highlighting discontinuities, and sequence boundaries [33]. The quality of the 2D regional seismic profiles was not very good therefore the profiles were reprocessed to remove the random noise, increase the resolution and enhance the reflection continuity; the acquisition and post processing parameters are shown in (Table 2). Despite the number of multichannel signal enhancement techniques has been practiced, the one which best preserves relative amplitudes and retains the signal character without amplitude distortion is frequency filtering [34]. In spite of the best efforts made in seismic data acquisition and processing, the seismic data still contains, to a variable degree important distortions such as sharp complex structures, attenuation of reflection energy which is compensated by Automated Gain Control (AGC), the presence of organized and random noise by frequency filtering, and time gain [35]. In the first step, a frequency filtering of signal processing was performed for each seismic profile to enhance the reflections continuity. In order to boost weak events and improve the interpretability of the seismic data, Trace AGC (Automatic Gain Control) was applied in the second step of refining the data. The Trace AGC scales the instantaneous amplitude value with the normalized Root Mean Square (RMS) amplitude over a specified window (values assigned for each profile are shown in Table 2). Most of the events improved by the application of Trace AGC. The Trace AGC is represented by the formula given below:

$$
\operatorname{TraceAGC}(t)=f(t) \times(1.5-(R M S / \max ))
$$

Where max is computed over the entire survey, RMS denotes the Root Mean Square (RMS) amplitude over a specified window. In the third step of the signal processing, the Time Gain was also applied to further refine the seismic images. The Time Gain scales the traces amplitudes of the input seismic data with $(1+t) \star G$, where $G$ is a constant specified value to enhance the interpretability of the seismic reflections. The signal processing was done very carefully in order to avoid generating artificial data in the seismic images.

\subsection{Reconstructing Stratigraphic Framework}

Figure 3 summarizes the stratigraphy of the Jurassic to Recent succession in offshore Indus Pakistan, modified after [30, 36-38]. Unconformities recognized in the region are also shown and are approximately dated using Geological time scale.

\subsection{Seismic to Stratigraphic Correlation}

In this study, well logs and check-shot data were used to identify key reflections in Cretaceous to Recent succession. Delineation and determination of the reflections 
Table 1: Details of Formation Tops of the wells used, measured in meters.

\begin{tabular}{|c|c|c|c|c|c|c|c|}
\hline Well Name & $\begin{array}{l}\text { Total Depth } \\
\text { (m) }\end{array}$ & $\begin{array}{c}\text { Recent } \\
\text { Sediments }\end{array}$ & $\begin{array}{l}\text { Miocene } \\
\text { (Gaj Fm) }\end{array}$ & $\begin{array}{c}\text { Oligocene } \\
\text { (Nari Fm) }\end{array}$ & $\begin{array}{c}\text { Eocene } \\
\text { (Ghazij \& Kirthar Fm) }\end{array}$ & $\begin{array}{c}\text { Paleocene } \\
\text { (Ranikot Fm) }\end{array}$ & $\begin{array}{c}\text { Cretaceous } \\
\text { (Mughal Kot Fm) }\end{array}$ \\
\hline W-2 & 2400 & $0-410$ & $410-795$ & $795-1650$ & Not Reached? & Not Reached? & Not Reached? \\
\hline W-3 & 2650 & $0-190$ & $190-390$ & $390-1002$ & $1002-1400$ & $1400-2100$ & $2100-2370$ \\
\hline$W-4$ & 3220 & $0-300$ & $300-580$ & $580-1620$ & $1620-2010$ & Not Reached? & Not Reached? \\
\hline$W-5$ & 2000 & $0-90$ & $90-210$ & $210-1790$ & $1790-1900$ & Not Reached? & Not Reached? \\
\hline$w-6$ & 2200 & $0-321$ & $270-580$ & $580-1430$ & Not Reached? & Not Reached? & Not Reached? \\
\hline$W-7$ & 3430 & $0-300$ & $300-590$ & $590-1650$ & Not Reached? & Not Reached? & Not Reached? \\
\hline W-8 & 2620 & $0-180$ & $180-380$ & $380-1000$ & Not Reached? & Not Reached? & Not Reached? \\
\hline W-9 & 3600 & $0-180$ & $180-420$ & $420-795$ & $795-1090$ & $1090-2080$ & $2080-2350$ \\
\hline
\end{tabular}

Table 2: Seismic Data Acquisition and Post Processing Parameter.

\begin{tabular}{|c|c|c|}
\hline Profile Name & Acquisition Parameters & Post Processing Parameters \\
\hline Profile-1 & $\begin{array}{l}\text { Profile Length }=78 \mathrm{Km} \text {, Record Length }=7 \mathrm{sec} \text {, Sample } \\
\text { Rate }=2 \mathrm{Msec}, \text { Recording Filter }=180 \mathrm{HZ} 72 \mathrm{DB} / \mathrm{OCT}, \\
\text { Source }=\text { Air Guns, Gun Depth }=6 \mathrm{~m} \text {, Receiver }=\text { DFS V, } \\
\text { Fold }=80 \text {, Polarity }=\text { Field Polarity Maintained Throughout } \\
\text { Processing and Display (Trough as Negative), Profile Type } \\
=\text { Post Stacked Migrated }\end{array}$ & $\begin{array}{l}\text { Frequency Filtering } \\
(\mathrm{Hf}=60 \mathrm{HZ}, \mathrm{Lf}=12 \mathrm{HZ}) \\
\text { Trace } \mathrm{AGC}=24 \\
\text { Time Gain }=1.8\end{array}$ \\
\hline Profile-3 & $\begin{array}{l}\text { Profile Length }=73.75 \mathrm{Km} \text {, Record Length }=7 \mathrm{sec} \text {, Sample } \\
\text { Rate }=2 \mathrm{Msec} \text {, Recording Filter }=180 \mathrm{HZ} 72 \mathrm{DB} / \mathrm{OCT} \text {, } \\
\text { Source }=\text { Air Guns, Gun Depth }=6 \mathrm{~m} \text {, Receiver }=\text { DFS V, } \\
\text { Fold }=120 \text {, Polarity }=\text { Field Polarity Maintained Throughout } \\
\text { Processing and Display (Trough as Negative), Profile Type } \\
=\text { Post Stacked Migrated }\end{array}$ & $\begin{array}{l}\text { Frequency Filtering } \\
(\mathrm{Hf}=12 \mathrm{HZ}, \mathrm{Lf}=6 \mathrm{HZ}) \\
\text { Trace } \mathrm{AGC}=15 \\
\text { Time Gain }=1.5\end{array}$ \\
\hline $\begin{array}{l}\text { Profile-7 } \\
\end{array}$ & $\begin{array}{l}\text { Profile Length }=65.5 \mathrm{Km} \text {, Record Length }=6 \mathrm{sec} \text {, Sample } \\
\text { Rate }=2 \mathrm{Msec}, \text { Recording Filter }=180 \mathrm{HZ} 54 \mathrm{DB} / \mathrm{OCT}, \\
\text { Source }=\text { Air Guns, Gun Depth }=7 \mathrm{~m} \text {, Receiver }=\text { DFS V, } \\
\text { Fold }=120, \text { Polarity }=\text { Field Polarity Maintained Throughout } \\
\text { Processing and Display (Trough as Negative), Profile Type } \\
=\text { Post Stacked Migrated }\end{array}$ & $\begin{array}{l}\text { Frequency Filtering } \\
(\mathrm{Hf}=28 \mathrm{HZ}, \mathrm{Lf}=12 \mathrm{HZ}) \\
\text { Trace } \mathrm{AGC}=16 \\
\text { Time Gain }=1.8\end{array}$ \\
\hline Profile-8 & $\begin{array}{l}\text { Profile Length }=67 \mathrm{Km} \text {, Record Length }=6 \mathrm{sec} \text {, Sample } \\
\text { Rate }=2 \mathrm{Msec} \text {, Recording Filter }=180 \mathrm{HZ} 54 \mathrm{DB} / \mathrm{OCT} \text {, } \\
\text { Source }=\text { Air Guns, Gun Depth }=7 \mathrm{~m} \text {, Receiver }=\text { DFS V, } \\
\text { Fold }=60 \text {, Polarity }=\text { Field Polarity Maintained Throughout } \\
\text { Processing and Display (Trough as Negative), Profile Type } \\
=\text { Post Stacked Migrated }\end{array}$ & $\begin{array}{l}\text { Frequency Filtering } \\
(\mathrm{Hf}=25 \mathrm{HZ}, \mathrm{Lf}=12 \mathrm{HZ}) \\
\text { Trace } \mathrm{AGC}=20 \\
\text { Time Gain }=2\end{array}$ \\
\hline Profile-12 & $\begin{array}{l}\text { Profile Length }=55.5 \mathrm{Km} \text {, Record Length }=6 \mathrm{sec} \text {, Sample } \\
\text { Rate }=2 \mathrm{Msec} \text {, Recording Filter }=180 \mathrm{HZ} 54 \mathrm{DB} / \mathrm{OCT} \text {, } \\
\text { Source }=\text { Air Guns, Gun Depth }=7 \mathrm{~m} \text {, Receiver }=\text { DFS V, } \\
\text { Fold }=80, \text { Polarity }=\text { Field Polarity Maintained Throughout } \\
\text { Processing and Display (Trough as Negative), Profile Type } \\
=\text { Post Stacked Migrated }\end{array}$ & $\begin{array}{l}\text { Frequency Filtering } \\
(\mathrm{Hf}=12 \mathrm{HZ}, \mathrm{Lf}=6 \mathrm{HZ}) \\
\text { Trace } \mathrm{AGC}=18 \\
\text { Time Gain }=2\end{array}$ \\
\hline
\end{tabular}

can be made by using synthetic seismograms, which describe the relationship of an event to a particular interface of sequence interfaces [39]. Figure 3 summarizes the regional stratigraphy the geological formations deposited with each tectonic activity along the Indian Plate margin. To illustrate the methodology used to tie the seismic data to the regional stratigraphy, the southwest to northeast trending line (Profile-7) across the platform area with well $\log$ information of the well W-1 were used (location of the profile and well is shown in Fig. 2). In Fig. 4, a synthetic seismogram and 2D seismic profile were displayed with regional stratigraphy.

Generation of synthetic seismogram was performed which permits the interpreter to tie time data (the seismic data) to depth data (the well data) by integrating over velocity profile. An impedance log and the reflection coefficient are generated from the velocity and density logs. The reflection coefficients are convolved with a seismic Ricker wavelet ( 45 Hertz peak frequency with a sampling rate of 2 milliseconds) to produce a synthetic seismic trace. The synthetic seismogram is then compared with the actual seismic traces at the well site (W-1) as shown in (Fig. 4). The traces at the well site were compared with the adjacent traces to assure that it was representative of similar part of the seismic section. The synthetic seismogram closely matches the key reflections of the seismic data. The well W-1 penetrated the most complete succession on the seismic profiles. The seismic reflections between 150 (Plio-Pliestocene) to 2000 milliseconds (Probably Late Cretaceous) are tied between the seismic Profile-7 and synthetic seismogram of the well $\mathrm{W}-1$, where the reflections from 0 milliseconds to 100 milliseconds (Recent Sediments) could not be tied because of the information missed in sonic data, however the density log (varying between 1.6 to $3 \mathrm{~g} / \mathrm{cc}$ ) is the representative of Plio-Pleistocene sediments composed of mixture of sandstone, shale, clay and conglomerates, deposited in the near shelfal region of the study area. Strong reflection and continues events can be correlated in the deeper portion in synthetic as well as surface seismic data which may represents thick Eocene carbonates and sandstone. The most complete CretaceousRecent reflections interpreted on seismic profiles are identified in Figs. 3 and 4, and are indicated in the studied seis- 


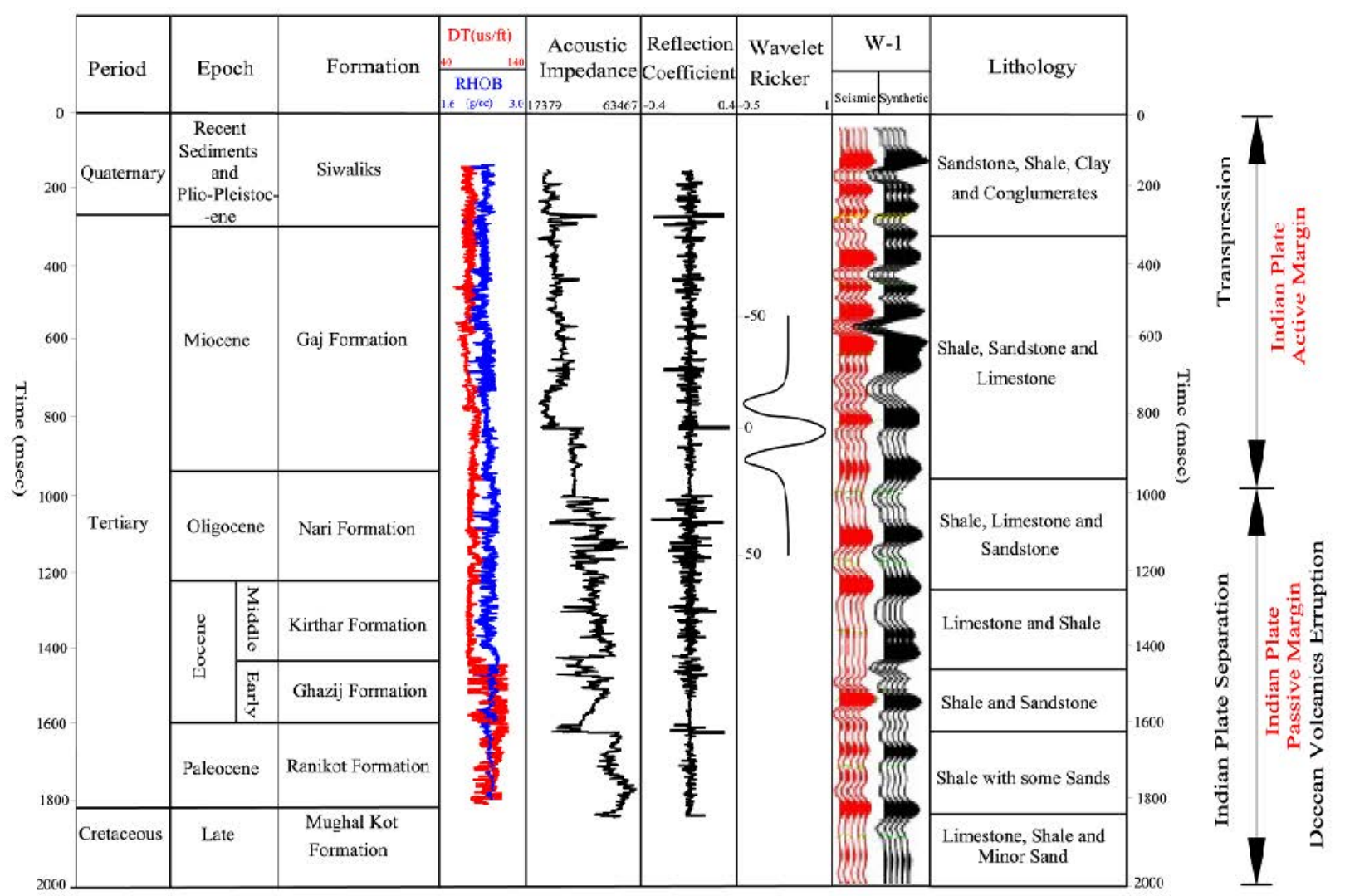

Figure 4: Well to Seismic Correlation. Synthetic Seismogram for the well W-1 tied to seismic Profile-7 with correlation to regional stratigraphy and major tectonic events along Indian Plate Margin.

mic lines. The reflections are generally high amplitude and continuous in some parts, and have been picked on the peak of the reflection wavelet, black positive amplitude as shown in Fig. 4, which corresponds to an increase in the acoustic impedance.

\subsection{Horizons and Faults Identification}

Conventional seismic interpretation implies picking and tracking laterally consistent seismic reflectors for the purpose of mapping geological structures, stratigraphy and reservoir architecture. The seismic sections are interpreted in terms of the geological formations, and the continuity and discontinuities in reflection pattern. The main purpose of the seismic interpretation is to relate the surface reflection seismic data to the subsurface stratigraphy and depositional facies [31]. The seismic data in SEG-Y format along with well data were loaded in a seismic interpretation software for interpreting horizons and faults. The lithofacies interpreted from well logs and formation tops were matched against reflections from seismic profiles. Horizons along each seismic profiles were marked on the basis of reflection continuity, impedance contrast, vertical and horizontal resolution and amplitude response, especially in areas where there was no well control. A total of 6 horizons/sequences were identified and marked namely, Cretaceous, Paleocene, Eocene, Oligocene, Miocene and Recent Sediments (Plio-Pleistocene to Late Quaternary). The seismic sections are divided into its constituent sequences, each sequence is analyzed in terms of internal deposition of reflection events and their character providing insights into the depositional environments. Faults on the seismic sections are recognized on the basis of discontinuity or abrupt termination in the subsurface seismic reflections and diffraction patterns mainly those with vertices [40]. Consistency of the fault traces was ensured at all levels. The interpreted profiles with horizons marked in black color solid lines and faults marked with black colored dotted lines (Figs. 5 to 9). The horizons marked were tied at different intersection points for ensuring consistency in all the lines of intersection in all the seismic section covering the entire survey. The analysis was rechecked in areas where there were misties or closure errors. 

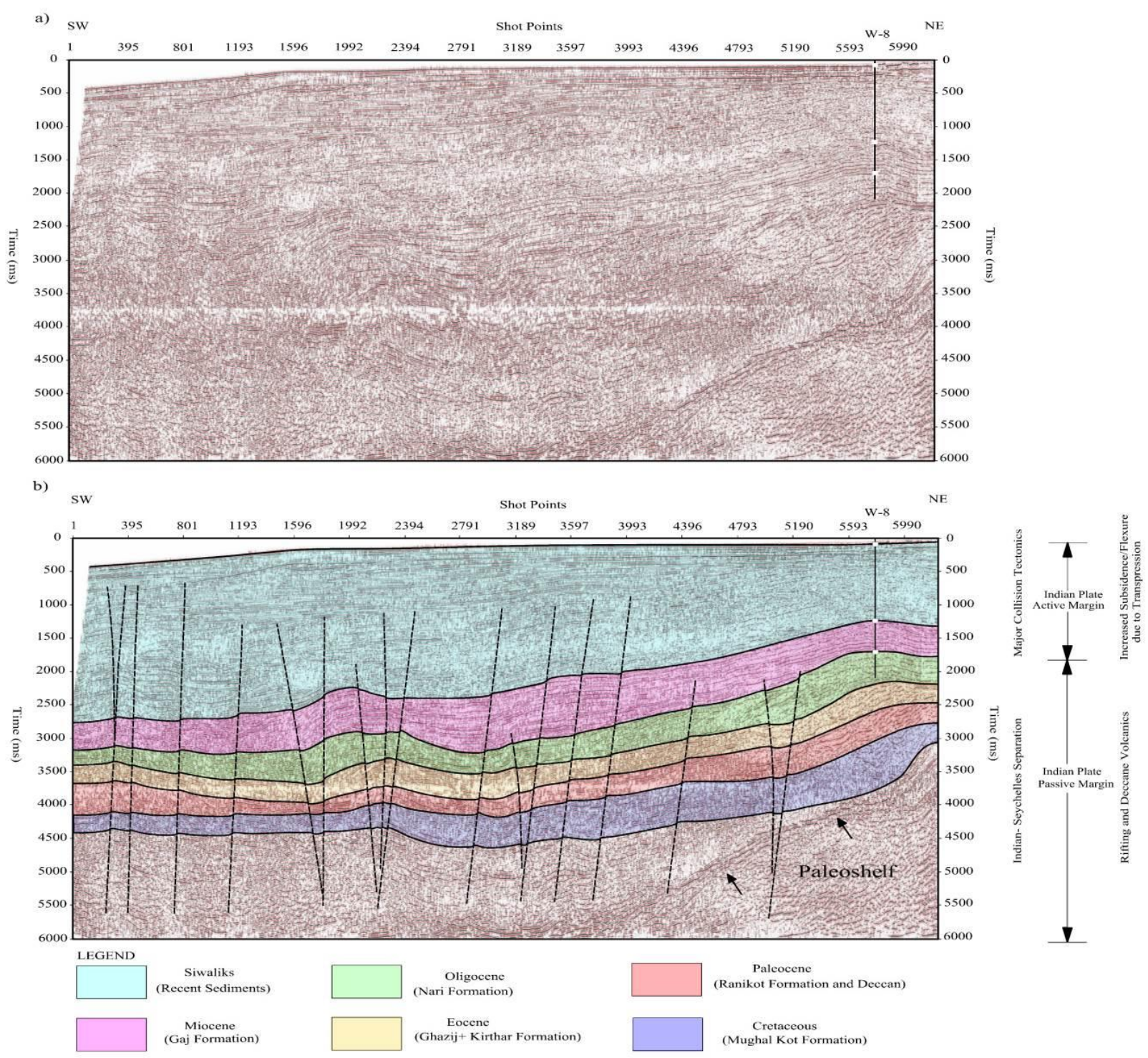

Figure 5: Interpreted regional seismic Profile-1 oriented in SW-NE direction. The dotted vertical lines in black color represent geological faults and horizontal color lines show horizons marked. Major tectonic events are shown on the right side.

\subsection{Depth Conversion and Growth History}

The layer-cake approach was used to convert the interpreted primary reflections into depth for each profile. In this method, for each profile, the thickness of the interval in the tied wells was divided by half the TWT of the respective interval in the seismic profile to provide apparent velocity. The apparent velocity for the interval was then utilized for depth conversion along each seismic profile. The depth of shallowest reflection (Recent Sediments, herein) is based on converting half the reflection time with the apparent velocity from the sea bottom/datum, whereas the depth of the deeper horizons was then estimated by adding successive thickness intervals downwards. A push up anticlinal structure was identified in the southwestern part of the study area along the Profile- 1 and 3. The cumulative growth history of the primary reflections in this push up structure was then computed by comparing the depth of key primary reflections from the crest and flanks/limbs (northeast limb and southwest limb) of the anticlinal structure. The cumulative growth rate is shown in (Fig. 12). 


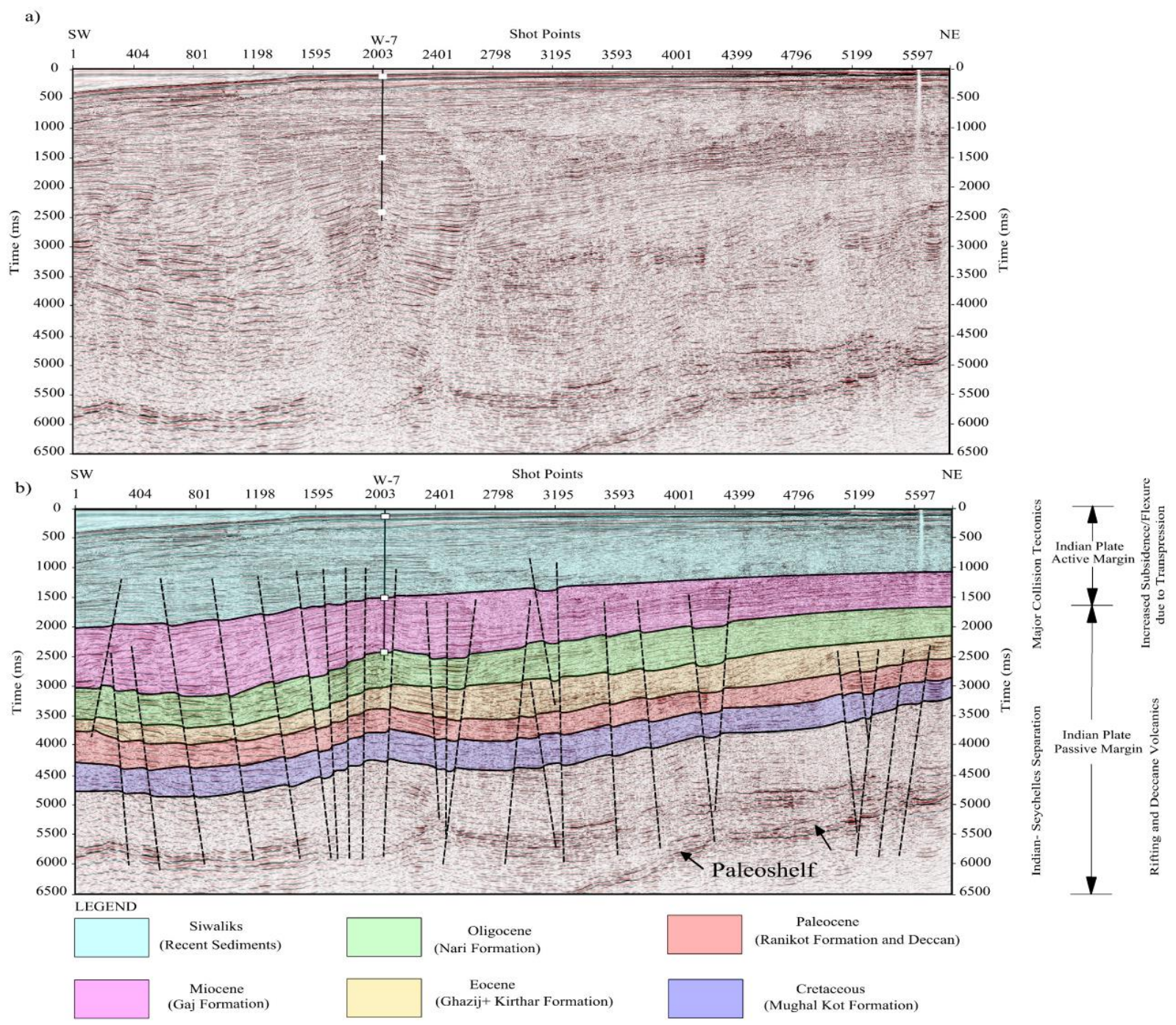

Figure 6: Interpreted regional seismic Profile-3 oriented in SW-NE direction. The dotted vertical lines in black color represent geological faults and horizontal color lines show horizons marked. Major tectonic events are correlated in the right side.

\section{Results and Discussion}

Utilizing the seismic regional profiles covering an area of $310 \mathrm{kms}$ in correlation with well log and outcrop data provided insights for understanding the seismo-stratigraphy and subsurface structure in relation to tectonics of the study area. The results are discussed in the following sections.

\subsection{Seismo-Stratigraphy}

In the present study we have identified six different seismic sequences based on high amplitude reflections and its geometry which can confidently be correlated on se- lected profiles. The profiles selected for regional seismic stratigraphic analysis are oriented in SW-NE, running from shelf to deep offshore area. The stratigraphy as shown in (Fig. 3) ranges from Cretaceous to Recent time, the rocks are mainly detrital and non-detrital of different ages with a thick sedimentary cover. Reflection configuration reveals gross stratification patterns from which depositional processes, paleotopography, and erosion can be interpreted. Seismic reflection configuration is the most obvious and directly analyzed parameter, stratal configuration is interpreted from seismic configuration, and refers to the geometric patterns and relations of strata within the stratigraphic unit [41], and these are common indicatives of depositional setting and processes, and later structural mo- 


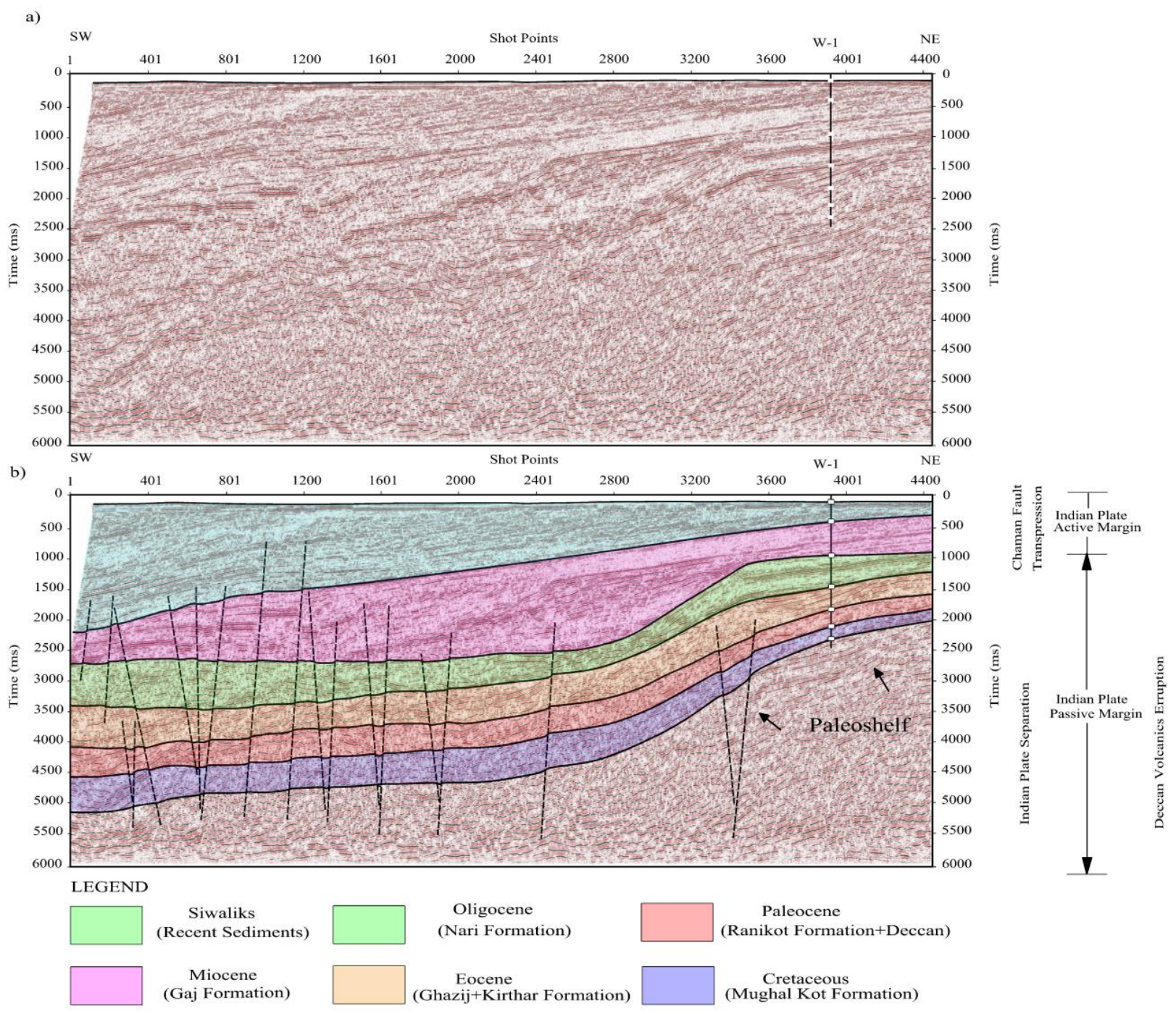

Figure 7: Interpreted regional seismic Profile-7 oriented in SW-NE direction. The dotted vertical lines in black color represent geological faults and horizontal color lines show horizons marked.

ment. In the following section, these primary reflections are briefly discussed (Figs. 5 to 9).

\section{Cretaceous Sequence (Mughal Kot Formation)}

The deepest reflector identified on five different seismic profiles (Figs. 5 to 9) in the present study coincides with the top of Late Cretaceous aged Mughal Kot Formation (nearly $140 \mathrm{Ma}$ ). The overlying interval between Cretaceous and Paleocene sequence is essentially non-reflective. The two reflections are regionally conformable, implying there was no pronounce structural growth during this part of the Cretaceous. The Mughal Kot Formation consists mainly of limestone, with interbedded shale and sandstone [42]. The average thickness of the formations increase from shelf to the offshore platform. Figure 5 shows, the seismic Profile-1 which is 78 kilometer long and runs southwest to northeast representing parallel to sub-parallel prograding reflections at the top (2800 to 3050 milliseconds) and chaotic at the base (4400 milliseconds). The reflections between 3000 to 4000 milliseconds in the south west are probably the representative of paleoshelf margin where base of Early Cretaceous onlapped. The Cretaceous sequence shows parallel to subparallel reflection configuration on all seismic profiles (Figs. 5 to 9) lying conformably on Paleocene sequence, which is interpreted as strata having sig- 


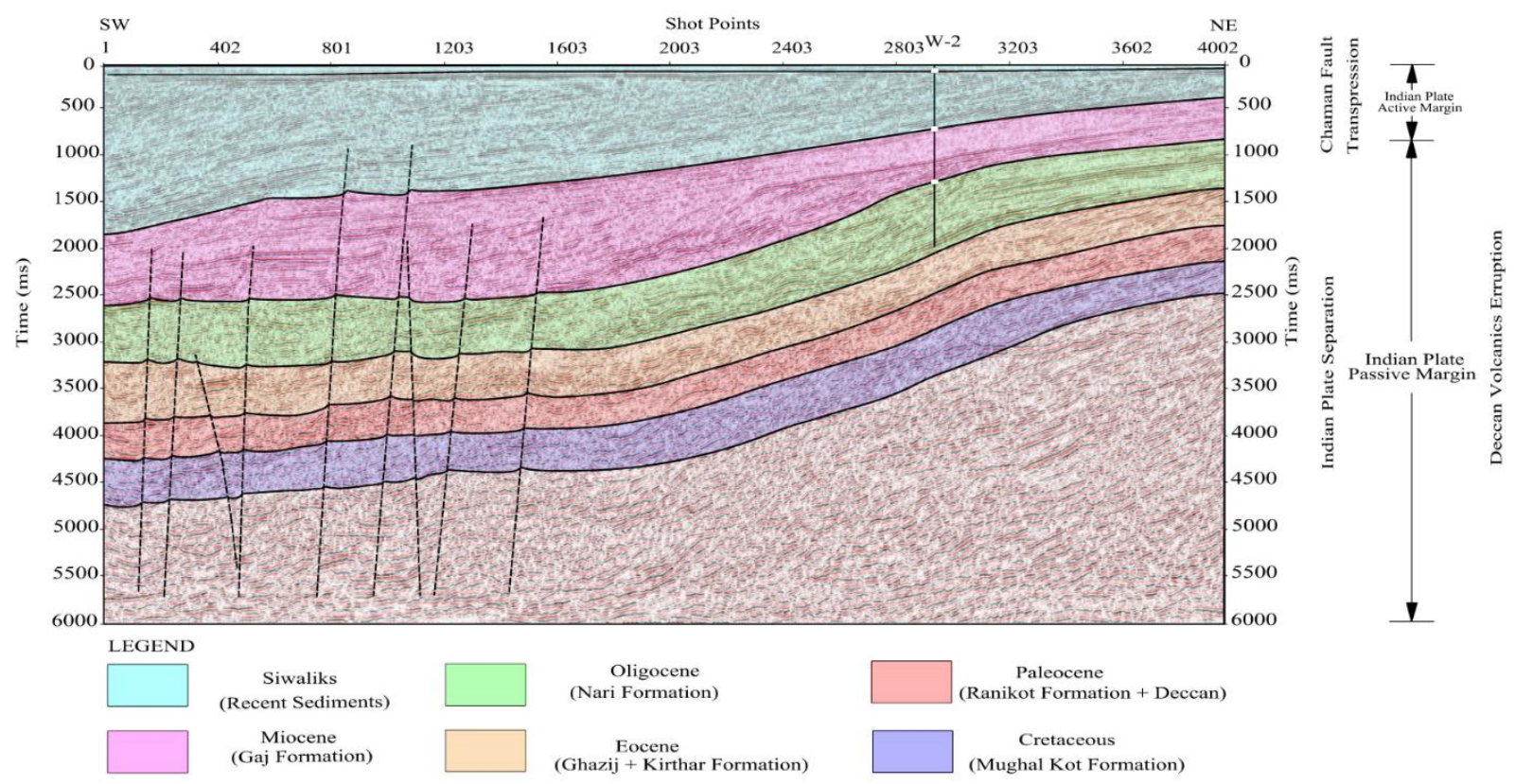

Figure 8: Interpreted regional seismic Profile-8 oriented in SW-NE direction. The dotted vertical lines in black color represent geological faults and horizontal color lines show horizons marked.

nificant deposition due to lateral outbuilding or porgardation.

\section{Paleocene Sequence (Ranikot Formation)}

The Paleocene sequence is bounded by the Cretaceous at the base and Eocene sequence at the top and is conformable above and below. The Paleocene sequence comprises of Ranikot Formation. However, the Upper Ranikot has only been encountered in one of the platform wells and consists mainly of interbedded shale and limestone [42]. The Lower Ranikot consists of sandstone interbedded with shale and layers of "basalt" (flood basalts of Deccan Trap). The Paleocene sequence shows parallel to wavy reflection configuration with high amplitudes and low frequency reflections throughout the study area (refer to Figs. 5-9). Mostly parallel near the shelf which indicates uniform sedimentation conditions. The reflections in the deep sea near southwest termination (Fig. 5, shot point 1593 to 2396 on seismic Profile-1 and Fig. 6, below W-7 on the seismic Profile-3) represent wavy pattern.

\section{Eocene Sequence (Ghazij and Kirthar Formations)}

The Eocene sequence (nearly $56 \mathrm{Ma}$ ) consisting of Ghazij and Kirthar Formations is encountered in all wells near the offshore platform area as well as offshore depression close to Murray Ridge. Ghazij Formation contains shale fa- cies with bands of some carbonates [13]. Kirthar Formation consists mainly of limestone interbedded with marlstone and calcareous shale [42]. The Eocene sequence shows parallel to subparallel and oblique-sigmoidal reflection geometry throughout the study area with progradation and onlap fill pattern in southwest. The small scale push up forming anticlinal geometry is interpreted on seismic Profile-1, 3 and 12 as shown in Figs 5a, b, 6a, b and 9. This push up structure is probably partly the result of basement blocks uplifting and partly due to present day compression along the Indian plate margin.

\section{Oligocene Sequence (Nari Formation)}

The Nari Formation of Oligocene age mainly consists of limestone interbedded with marlstone and calcareous shale, commonly with bands of calcareous sandstone, especially in the upper part [42]. The Oligocene sequence is characterized by parallel to subparallel reflection patterns of moderate to good continuity and medium range amplitudes dipping towards northeast. These reflections can be traced over all of the seismic profiles with confidence. The reflections frequency is moderate. In the northeastern part of the study area, it pinches out against elevated region associated with Murray Ridge. The Oligocene strata during its deposition were occasionally subjected to erosion by the shifting channels of Proto-Indus River, which were subsequently filled by clastics during Middle to Late 

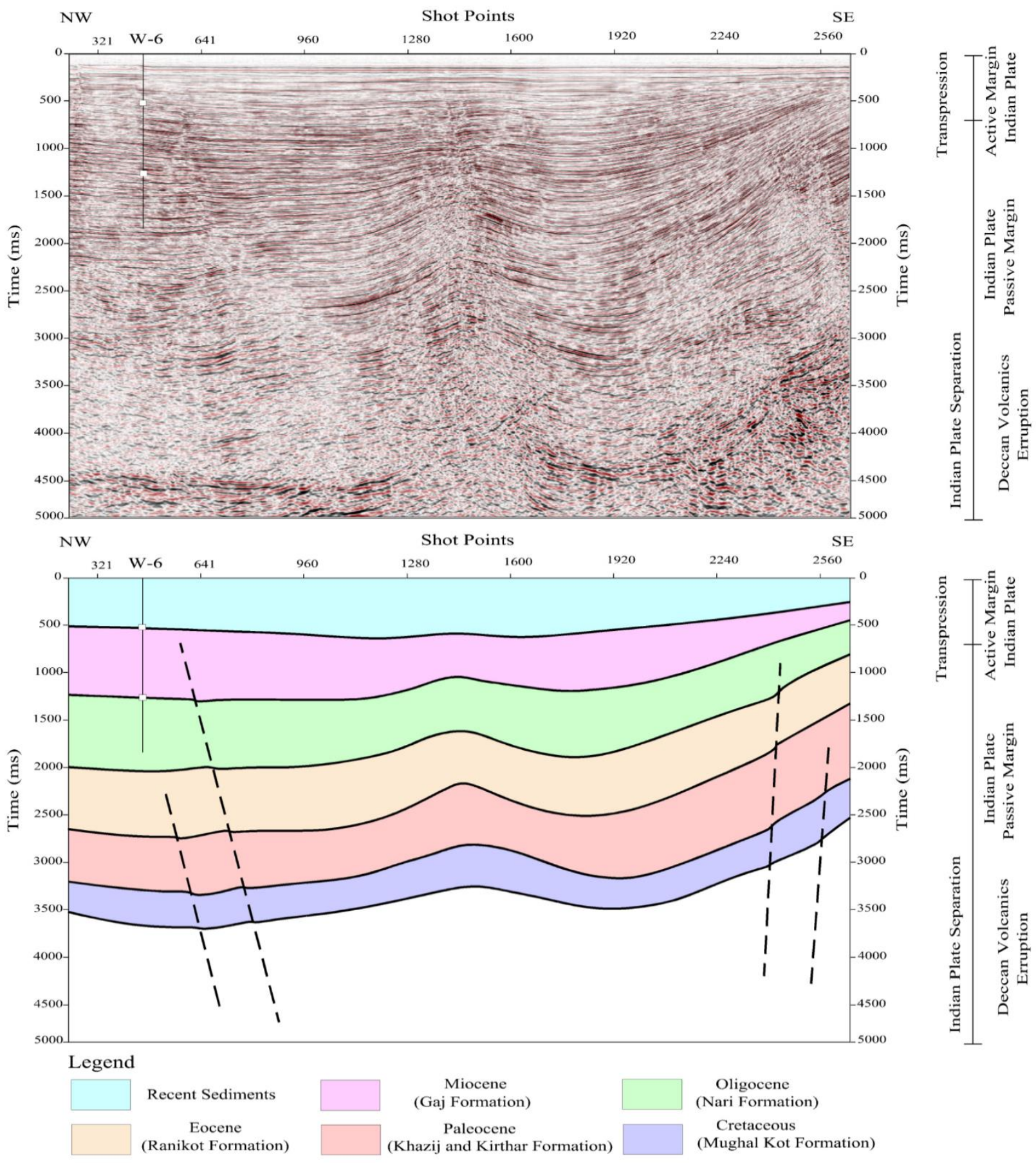

Figure 9: Interpreted regional seismic Profile-12 oriented in NW-SE direction. The dotted vertical lines in black color represent geological faults and horizontal color lines show horizons marked.

Miocene as well as during Pliocene. Normal faults of variable scales are observed and suggest a phase of transpression due to collision of the Indian-Eurasian plates.

\section{Miocene Sequence (Gaj Formation)}

Miocene sequence (approximately aged $23 \mathrm{Ma}$ ) is interpreted confidently on all seismic profiles which is overlain by Recent sediments (Plio-Pleistocene to Quaternary). The Miocene aged Gaj Formation is about 60-70 meters 
thick in the offshore Platform area and is present in all the wells drilled in the region. In the Depression area maximum thickness of over 2750 meters was encountered in the southern most offshore well [42]. The overall thickness increases towards the depression. This formation comprises carbonate facies with intercalations of calcareous clastics. The Miocene sequence has been reported as source rock, and organic matter is composed of type II and type III kerogens while maturation occurred during the late Miocene and Pliocene with generation continuing today [43]. The Miocene sequence shows oblique sigmoidal reflection pattern on all regional seismic profiles interpreted (Figs. 5 and 6). The reflectors amplitude is moderate to high with high to moderate frequencies. The top surface of the Miocene sequence in southwestern part represents an erosional profile with high dip values near the shelfal region that decrease towards northeastern part. Considerable thicknesses of the Miocene sequence were eroded over the structural highs (push up structure) in the study area as a result of widespread basement uplift. Rapid uplift of the structures was probably due to the reactivation of the basement structures during Indian plate collision, Fig. 9 shows clearer picture of the anticlinal geometry.

\section{Recent Sediments (Siwaliks)}

The shallowest reflections imaged in the study area are Recent Sediments (Plio-Pleistocene to Quaternary) which consists of a series of cycles of marginal to non-marine clastic sediments. These are the recently deposited sediments which are known as Siwaliks eroded from Himalayas, drained by Indus River and, deposited above the Miocene sequence. These sediments are mainly calcareous, highly fossiliferous clastics of varying thickness with intercalations of clay, siltstone, and sandstone with conglomerate bands [42]. This particular sequence shows parallel to subparallel and divergent reflection configuration. The divergent reflection configuration of this sequence is characterized by a wedge-shaped unit in which most of the lateral thickening is accomplished by thickening of individual reflection cycles within the unit. Numerous normal faults have been identified on interpreted regional seismic profiles in this sequence, which could be because of the ongoing activities along Indian plate active margin.

\section{Stratigraphic Correlation}

The stratigraphy of the offshore Indus Basin was significantly affected by the separation of the Gondwanaland during the Mesozoic era and northward drift of the Indian Plate, post-rift downwarpping and sedimentations, and shear zone tectonics along its western margin during the Middle Cenozoic era. Pre-drift sequence overlies a buried acoustic basement. Initial detritus derived from the rapid erosion of the Karakoram, which was uplifted after the Eocene collision of India with Eurasia. Uplift of the Karakoram combined with Late Oligocene to Early Miocene sea-level fall.

Through well to seismic tie, the horizon identified in the well can be referred to one particular reflector on the seismic section. Further to comprehend the regional stratigraphic framework of the formations in the study area, a correlation of wells in two different directions was done. The wells were selected perpendicular and as well as parallel to the seismic profiles to correlate regional stratigraphy. Fig. 10a, b shows the regional wells correlation in southeast direction. Two suits of logs (Gamma Ray and Sonic/DT) were chosen for regional stratigraphic correlation for the study area. Gamma Ray log is used in sedimentary rocks as a shale indicator as it exhibits higher radiation levels in front of shales and clay whereas lower radiation levels in front of sandstone and limestone or dolomites [44]. The sonic log (DT) measures the travel time of an elastic wave through the formation. The sonic log can identify the lithologies, high velocities usually indicate carbonates, middle velocities indicate sands and low velocities, shale [45]. The stratigraphic correlation of the offshore Indus Basin is complicated by extreme lateral variations in the lithologies, however in the present study, the formations are correlated by major sequences such as Recent Sediments, Miocene, Eocene, Paleocene and Cretaceous sediments. The deepest formation encountered is Mughal Kot Formation of Cretaceous age. The rock formations are mainly divided into clastic rocks which are composed of (sandstone, siltstone, shale and conglomerates) and carbonate rocks (limestone and dolomite).

The wells W-2, W-5, W-8 and W-9 are located in offshore depression whereas $\mathrm{W}-3$ and $\mathrm{W}-4$ are located in offshore Platform area. In general, as shown in Fig. 10a, b, the basin deepens in the southeast and central part of the region with deepest part observed at wells W-8 and W-9. Beyond this location, erosion and basement uplift has resulted in decrease in basin depth. Fig. 10a represents the correlation of wells from NW to SE. A general deepening is observed towards the central and south eastern part. Deepest location in the offshore depression is observed in the vicinity of W-9 which coincides the deeper part of the platform area in the region. In the well W-5, which is located on the offshore depression near Murray Ridge, the Early Cenozoic and Late Mesozoic succession (Paleocene-Cretaceous) is 


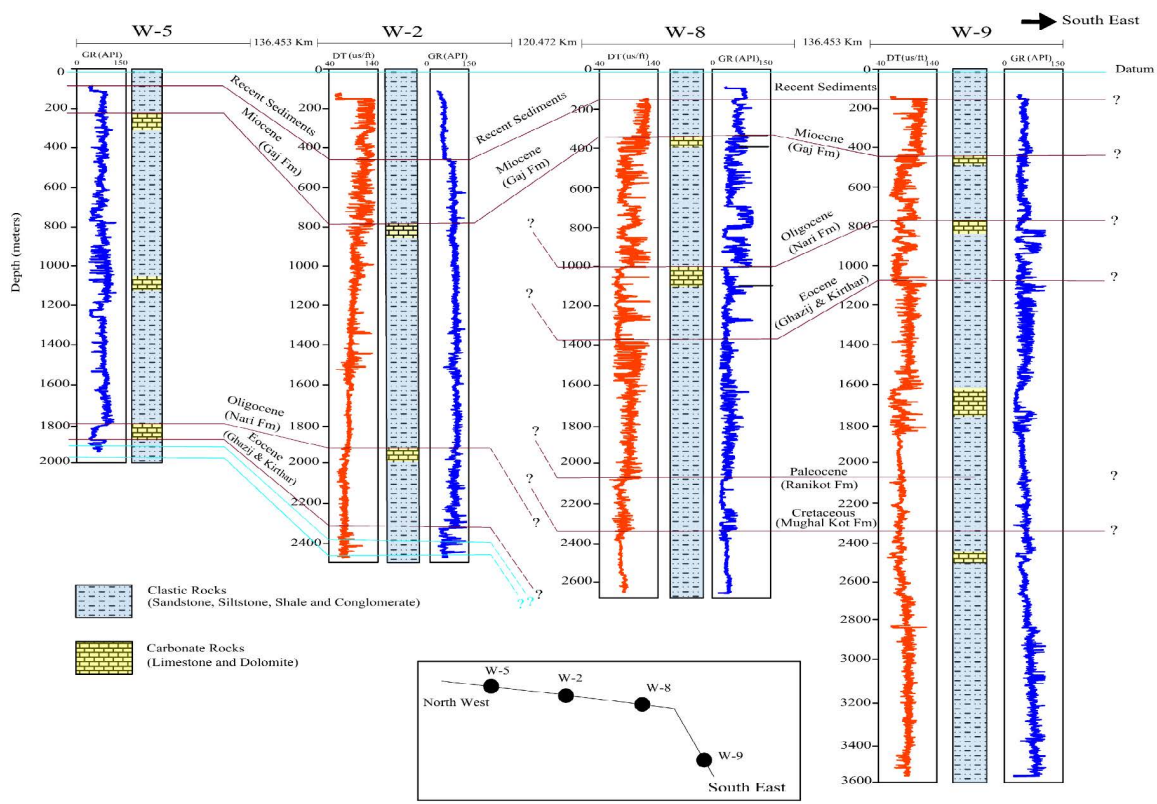

(a)

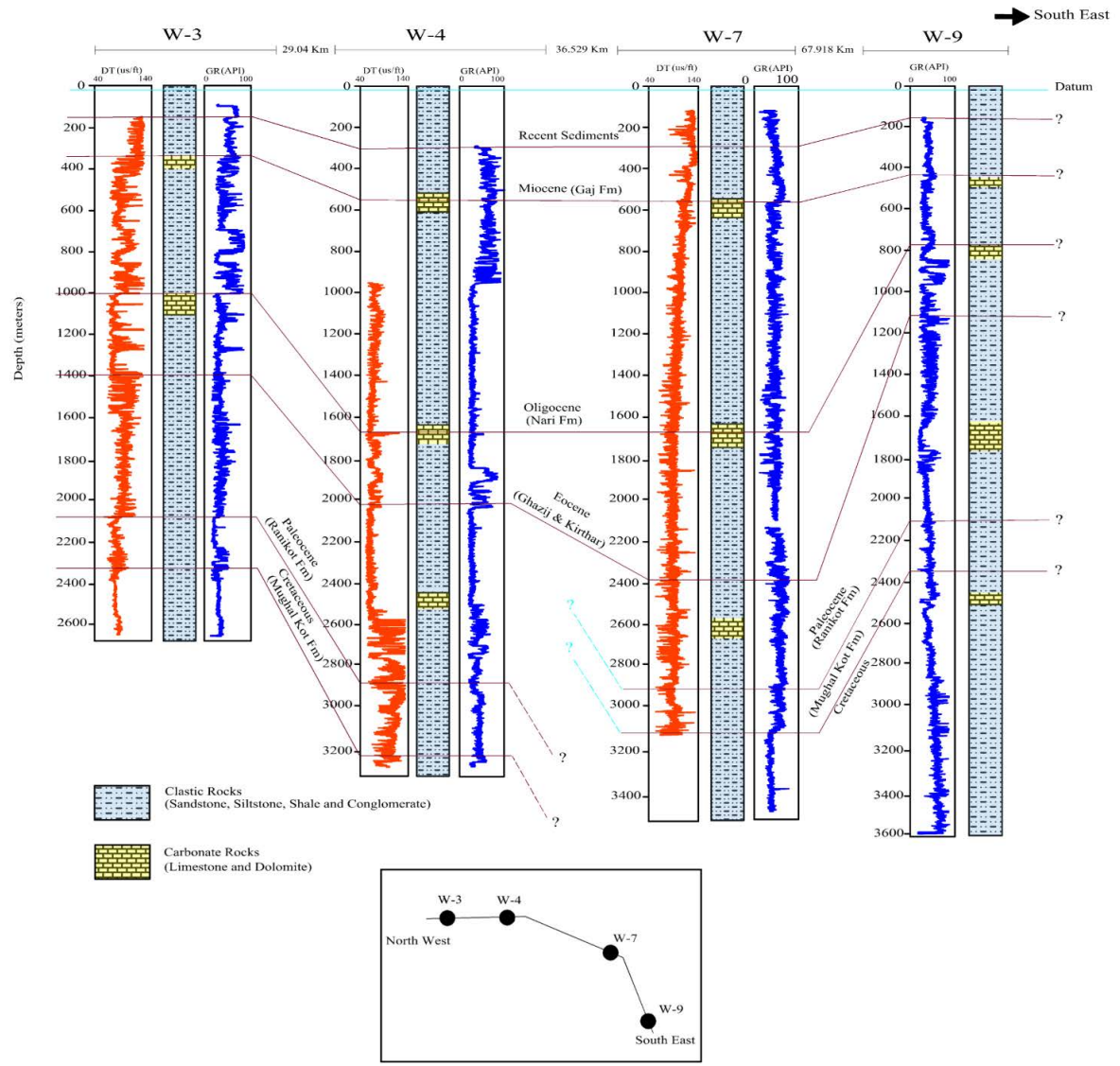

(b)

Figure 10: (a) Well Correlation for the wells W-5, W-2, W-8 and W-9 for the study area. Location shown in Figure 2. (b) Well Correlation for the wells W-3, W-4, W-7 and W-9 for the study area. The orientation of wells is South East. Location shown in Figure 2. 


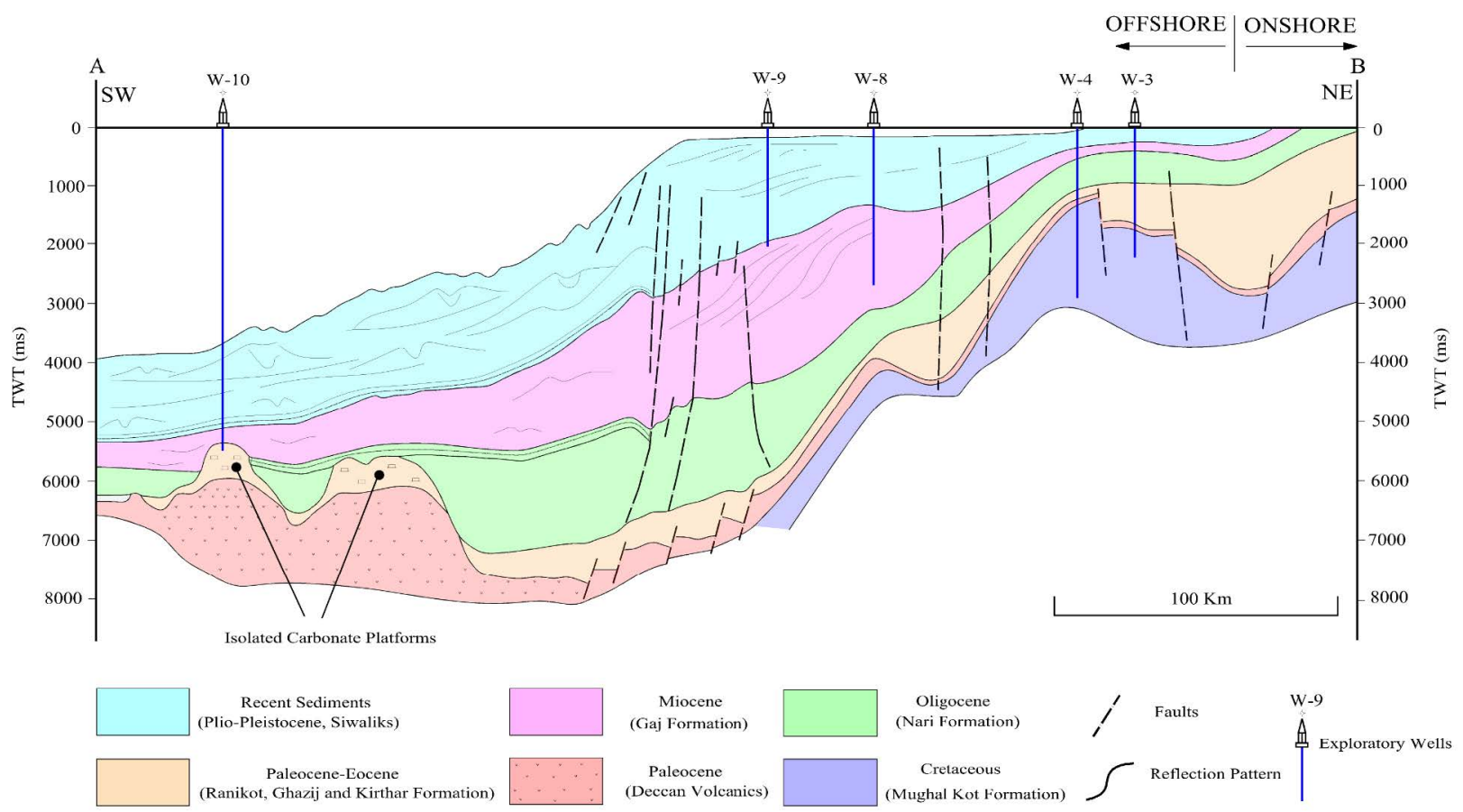

Figure 11: Regional Geoseismic Model for the offshore Indus Pakistan (Revised after Carmichael et al., 2009).
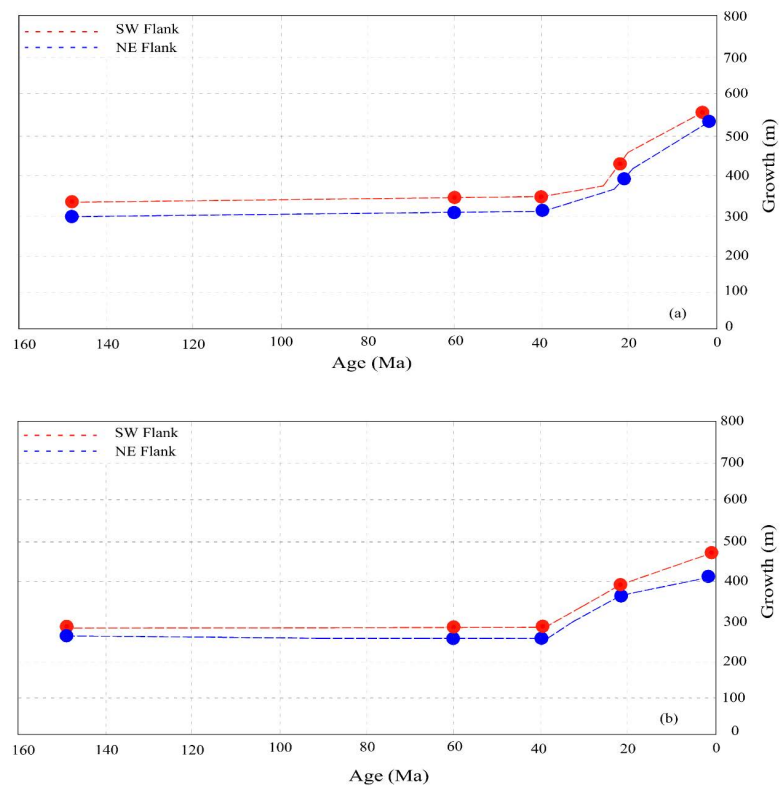

Figure 12: Structural growth computation along southwest and northeast flanks of the push up structure (a) Profile-1 (b) Profile-3.

missing (Figs. 2 and 10a). On the basis of regional correlation, it is suggested that the Paleocene-Cretaceous succession in W-5 is eroded due to uplift along Murray Ridge. In addition, the Cretaceous to Oligocene succession is missing in the vicinity of W-2 probably due to erosion of shelfal sediments. Furthermore, the formations encountered in offshore depression in Fig. 10a cannot be correlated in the northeastern direction because the wells drilled reach only Eocene strata. Nevertheless, the well W-9 penetrated the most complete succession up to Cretaceous in the study area. This succession cannot be correlated towards northwest probably due to uplift in the basement blocks. The offshore depression further deepens towards southeast. The well W-9 is drilled upto approximately 3600 meters where the deepest formation encountered is Cretaceous aged Mughal Kot Formation. The thickness of Siwaliks is comparatively less in W-5 due to present day uplift along the Murray Ridge.

Fig. 10b represents the correlation of the wells in NWSE direction. The wells on northwestern side (W-3, W-4) are drilled on offshore platform area. A general deepening is observed towards southeast (offshore depression). The depth decreases in the vicinity of W-3 and W-4 probably due to uplift in basement blocks. The deepest part is observed in W-9 whereas shallowest part of the basin in W-3. The Cretaceous-Paleocene succession in W-4 are missing on offshore platform which suggests the sediments are possibly eroded due to sub areal exposure. Furthermore, the correlation cannot be achieved towards further southeast beyond W-9 because the formations lie deeper. However, the formations cannot be correlated towards northwestern side because W-4 drilled up to Eocene strata only. 
The thickness of the Recent sediments (Siwaliks) increases towards southeast. The thickness of Siwaliks reaches to approximately $700 \mathrm{~m}$ in W-9. Fig. 11 shows a final geoseismic model modified after [17], representing the chronostratigraphic chart based on well control points in the offshore Indus Pakistan.

\subsection{Interpretation and Tectonic Implications}

An attempt has been made to show that the stratigraphic features and structure observed in a series of seismic sections from offshore Indus Pakistan are a consequence of tectonic activities and/ or eustasy. The present study conceptualizes the structural geometry and stratigraphy of the offshore Indus Basin by using seismic interpretation procedure. The most remarkable tectonic setting in the region is represented by the normal faulting and by the basement uplift which divides the rifting and transpression stages [46].

On the basis of available seismic and well data, six seismic sequences have been identified on seismic record with complex normal faulting throughout the study area and a strike slip component in some of the stratigraphic levels in southwestern part of the study area as shown in (Figs. 5 to 9). The seismic reflection configuration is complex along each sequence which mainly consists of parallel to subparallel, sigmoidal and divergent geometries. The interpretation of regional seismic profiles clearly reveals that the shelf is gradually prograding from northeast more towards southwest resulting in increased sedimentation which is probably from Karachi Platform. [16] reported this sedimentation is originating from the north. Several unconformities have been identified by previous researchers $[47,48]$. A paleo-shelf has been identified on regional seismic Profile-1, Profile-7 and Profile-8 (Figs. 5, 7 and 8) between 3500 to 5500 milliseconds which is overlain by Cretaceous sequence. This paleo-shelf is interpreted to be originated during the separation of Indian plate from African plate in the Late Jurassic, which was the time of rifting. It is further interpreted that the sea level was at its highstand and the accommodation space was enough to deposit sediments from Cretaceous to Recent age. This paleo-shelf is onlapped by sediments of high amplitude, high frequency and discontinuous pattern of seismic reflection, since the drilling has not yet reached this depth therefore the age of these sediments is unknown. Based on the present day position of continental shelf in the Miocene sequence, we inferred that there is considerable shift of 31.5 kilometers of the shelf towards southwest probably representing regression pe- riod due to falling stage of the sea level. Number of high angle normal faults extending down to the deep reflectors with horst and graben geometry have been identified on all seismic profiles. Sedimentary growth across these faults is mostly contained within shale-prone pre-shelf sediments, and their throw decline upwards to zero into the sandy clastic rocks above. A small pushup structure, dipping towards southwest has been interpreted between Eocene to Recent sediments on regional seismic Profile1, Profile-3 and Profile-12 (Figs. 5, 6 and 9, respectively) ranging from 1800 to 3800 milliseconds. This particular structure in the region seems to be the result of recent ongoing tectonic activities such as transpression along the Chaman transform fault or probably uplifting of Murray Ridge and basement blocks. Buried, abrupt and sharp vertical fault offsets recognized on the eastern side of the Murray Ridge [36] could correspond to the northward prolongation of the fracture zone that used to form the Miocene India-Arabia plate boundary. [49] documented two major episodes of deformation along the Indian-Arabian plate boundary at $\sim 8-10 \mathrm{Ma}$ and $\sim 1.9 \pm 0.9 \mathrm{Ma}$, the first episode is marked by the system of folds linked to the main uplift of the southern Murray Ridge and the first uplift of the northern Murray Ridge. The Rift basins of the Indo-Pak offshore and coastal region came into existence during the northward drift of the Indian plate as a consequence of the tension generated by the anticlock-wise rotation of the moving plate. An alternate suggestion to explain structural development is the counter effects/extension of the Tertiary anti-clockwise rotation of the plate. Under these circumstances, the area on the trailing margin may subside and deform into extensional structures to accommodate space. The evidences of extensional phenomenon (small scale spreading) along Murray Ridge have been attributed to such an anti-clockwise rotation [50].

An attempt has been made to compute the structural growth along the NE and SW flanks of the push up structures observed on seismic records (Fig. 12a, b). The cumulative growths of this pushup structure/anticline are plotted from the top of the anticline to the SW and NE flanks, the results are shown in (Figs. 12a, b). The structural growth was episodic in the study area but the timing is almost same which was initiated in the Late Eocene. The pushup structure is imaged on SW-NE dipping profiles (Profile-1, 3, and 12) as shown in (Figs. 5, 6 and 9). The total growth of the anticline on its southwest flank of Profile- 1 is approximately is $230 \mathrm{~m}$ whereas $220 \mathrm{~m}$ on Profile-3. Similarly, the cumulative growth computed along the northeastern flank of the anticlinal structure is approximately $248 \mathrm{~m}$ on Profile- 1 and $165 \mathrm{~m}$ on Profile-3. In the case of Cretaceous and Paleocene sequence, the structural growth is 
comparatively not prominent. The majority of the growth along Profile-3 in Fig. 12a, b is evident in Eocene-Recent time which is attributed to present day compression in the region probably either due to basement blocks uplift or transpression along the Indian Plate margin.

\subsection{Hydrocarbon Potential}

A total of 15 wells have been drilled in the offshore Indus, out of these, few wells did not reach the objective reservoirs due to technical difficulties while other wells appear to have been drilled on improper potential zone. The source rocks analyses of shale samples from wells drilled indicate the presence of hydrocarbon maturation in sediments ranging in age from Early to Middle Miocene. Miocene and Eocene aged carbonates and sandstones seem to be the objective reservoirs [17]. The possible hydrocarbon traps in the region are horst geometries, small anticlines, and stratigraphic traps. The present study helped in interpreting the stratigraphy, nature of faults and imaged subsurface structure more precisely in comparison to previous studies, therefore it would assist in achieving hydrocarbon discoveries.

\section{Conclusions}

The offshore Indus Basin, which is an Atlantic type passive continental margin of the Indian Plate provided an excellent location to study the impact of early rifting and present day collisional tectonics on subsurface structure and stratigraphy. The seismic reflection data interpretation in the study area shows overall normal faulting and an anticlinal pushup structure oriented SW-NE. The normal faulting in the region is representative of rifting process initiated in the Mesozoic. The pushup structure in the Late Eocene to Recent sediments is attributed to compressive tectonics of Indian-Eurasian plate collision commenced and probably due to basement uplift. Six mappable seismic sequences have been identified on seismic records. Previous studies carried out in the offshore Indus couldn't describe complete stratigraphic framework and true subsurface geological structures. In the light of geological settings and our results, we concluded that the regional stratigraphy and subsurface structure of the offshore Indus Pakistan is controlled by the tectonic activities along Indian plate together with uplifting in Murray Ridge and/or basement. We further infer that, the past exploration disappointments in the region were due to lack of understanding of subsurface structures and formations trend, which are helpful in defining petroleum system and nature of traps. Our findings could also be useful for carrying out hydrocarbon exploration activities in the region and understanding the tectonostratigraphy of the worldwide passive continental margins.

Acknowledgement: The authors are thankful to Directorate General of Petroleum Concession (DGPC), Pakistan, Chinese Academy of Sciences, Beijing, China, The World Academy of Sciences (TWAS), Italy and Schlumberger China (Petrel Software License provision) for supporting this research. The research was funded by the National Natural Science Foundation of China (Grant No. 41730425), and was also supported by National Major Projects of China (Grant No. 2017ZX05008-007).

\section{References}

[1] Jaswal T.M., Maqsood T., Structural geometry of the Offshore Indus basin, Pakistan, Pakistan Association of Petroleum Geologists manual. Annual Technical conference, 2002, 47-62.

[2] Molnar P., Tapponnier P., Cenozoic tectonics of Asia: Effects of a continental collision. Science, 1975, 189: 419-426.

[3] Clift P.D., Shimizu N., Layne G.D., et al. Development of the Indus Fan and its significance for the erosional history of the Western Himalaya and Karakoram. Geological Society of America Bulletin, 2001, 113; 1039-1051.

[4] Clift P., Shimizu N., Layne G., et al. Fifty-five million years of Tibetan evolution recorded in the Indus Fan. Earth Observing System (EOS). Transactions American Geophysical Union, 2000, 81: 277-281.

[5] Jacob K.H., Quittmeyer R.L., The Makran region of Pakistan and Iran: Trench-Arc system with active plate subduction. Geodynamics of Pakistan. Geological Survey Pakistan, Quetta, 1979, 305-317.

[6] Lawrence R.D., Yeats R.S., Khan S.H., et al. Crystalline rocks of the Spinatizha area, Pakistan Journal of Structural Geology, 1981, 3; 449-457.

[7] Biswas S.I., Rift Basins in Western Margin of India and their Hydrocarbon Prospects with Special Reference to Kutch Basin. American Association of Petroleum Geologists Bulletin, 1982, 66:1497-1513.

[8] Parker E.S., Gealey W.K., Plate Tectonic Evolution of Western Pacific-Indian Ocean Region. In: Proceedings. The Environment and Policy Institute/Asian Council on Petroleum/Committee for Coordination of Joint Prospecting for Mineral Resources Workshop on the Geology and Hydrocarbon Potential of the South China Sea and Possibilities of Joint Development, Honolulu, 1983, 22-26.

[9] Naini B.R., Talwani M., Structural framework and the evolutionary history of the continental margin of western India. American Association of Petroleum Geologists Bulletin, 1983, 34: 167191. 
[10] Norton I.O., Sclater J.G., Indian Ocean and break-up of Gondwanaland. Journal of Geophysical Research, 1979, 84: 68036830.

[11] McGowran, B., 1977, Maastrichtian to Eocene foraminiferal assemblages in the northern and eastern Indian Ocean region: correlations and historical patterns: Indian Ocean geology and biostratigraphy, p. 417-458.

[12] Fisher R.L., Sclater J.G., Mckenzie D.P., Evolution of the Central Indian Ridge, western Indian Ocean. Geological Society of America Bulletin, 1971, 82: 553-562.

[13] Quadri V.N., Shuaib S.M., Hydrocarbon Prospects of southern Indus basin Pakistan, American Association of Petroleum Geologists Bulletin, 1986, 70: 730-747.

[14] Shuaib S.M., Geology and hydrocarbon potential of offshore Indus basin, Pakistan, American Association of Petroleum Geologists Bulletin, 1982, 53: 180-1499.

[15] McHargue T.R., Webb J.E., Internal geometry, seismic facies, and petroleum potential of canyons and inner fan channels of the Indus submarine fan. American Association of Petroleum Geologists Bulletin, 1986, 70: 161-180.

[16] Daley T., Alam Z., Seismic stratigraphy of the offshore Indus Basin. Geological Society London Special Publications, 2002, 195: 259-271.

[17] Carmichael S.M., Akhter S., Bennett J.K., et al. Geology and hydrocarbon potential of the offshore Indus Basin, Pakistan. Petroleum Geoscience, 2009, 15: 107-116.

[18] Clift P., Gaedicke C., Edwards R., et al. The stratigraphic evolution of the Indus Fan and the history of sedimentation in the Arabian Sea. Marine Geophysical Research, 2002, 23: 223-245.

[19] Clift P.D., Kroon D., Gaedicke C., Craig J., Tectonic and climatic evolution of the Arabian Sea region: an introduction. Geological Society, London, Special Publications, 2002, 195: 1-5.

[20] Kolla U., Coumes F., Morphology, internal structure, seismic stratigraphy and sedimentation of Indus Fan. American Association of Petroleum Geologists Bulletin, 1987, 71: 650-677.

[21] Richard I.C., Carmichael S., Bennett J., et al. Variability in the crustal structure of the West Indian Continental Margin in the Northern Arabian Sea. Geological Society of London, Petroleum Geoscience, 2010, 16: 257-265.

[22] Chatterjee S., Scotese C.R., The breakup of Gondwana and the evolution and biogeography of Indian plate. Proceedings of Indian National Science Academy, 1999, 65: 397-425.

[23] Chatterjee S., Scotese C.R., The wandering Indian plate and its changing biogeography during the Late Cretaceous-Early Tertiary period. In: Bandopadhyay, S. (Ed.), New Aspects of Mesozoic Biogeography. Springer-Verlag, Berlin Heidelberg, Germany, 2010, 105-126.

[24] Chatterjee S., A kinematic model for the evolution of the Indian plate since the Late Jurassic. In: Chatterjee, S. Hotton, N. (Eds.), New Concepts in Global Tectonics. Texas Tech University Press, Lubbock, United States of America, 1992, 33-62.

[25] Dietz R.S., Holden J.C., Reconstruction of Pangaea: Breakup and dispersion of continents, Permian to Present. Journal of Geophysical Research, 1970, 75: 4939-4956.

[26] König M., Jokat W., Advanced insights into magmatism and volcanism of the Mozambique Ridge and Mozambique Basin in the view of new potential field data. Geophysical Journal International, 2010, 180: 158-180.

[27] Eagles G., König M., A model of plate kinematics in Gondwana breakup. Geophysical Journal International, 2008, 173: 703-
717.

[28] Royer J.Y., Coffin M.F., Jurassic to Eocene plate tectonic reconstruction of the Kerguelen Plateau region. Proceedings of the Ocean Drilling Scientific Results, 1992, 120: 917-924.

[29] Storey M., Mahoney J.J., Saunders A.D., et al. Timing of hot spotrelated volcanism and the breakup of Madagascar and India. Science, 1995, 267: 852-855.

[30] Gombos A.M., Powell W.G., Norton I.O., The tectonic evolution of western India and its impact on hydrocarbon occurrences: an overview. Sedimentary Geology, 1995, 96: 119-129.

[31] Gadallah M.R., Fisher R., Exploration Geophysics. SpringerVerlag Berlin Heidelberg, XXII, 2009, 266.

[32] Harms J.C., Southard J.B., Walker R.G., Fluvial deposits and facies models. Structures and Sequences in Clastic Rocks. Society of Economic Paleontologists and Mineralogists Short Course Notes 9, Tulsa, United States of America, 1982, 851.

[33] Barala S., Mohanty P., Enhancement of geologic interpretation using a new poststack seismic attribute. Society of Exploration Geophysicists Technical Program (Expanded Abstracts), Dallas, United States of America, 2016, 1677-1681.

[34] Yilmaz O., Stephen M.D., Seismic Data Analysis: Processing, Inversion, and Interpretation of Seismic Data, Society of Exploration Geophysicists, United States of America, 2000, 255.

[35] Jain S., Some techniques of enhancing seismic reflection data for stratigraphic interpretation. Canadian Society of Exploration Geophysicists, 1985, 21: 15-29.

[36] Edwards R.A., Minshull T.A., White R.S., Extension across the Indian-Arabian plate boundary: the Murray Ridge. Geophysical Journal International, 2000, 142: 461-477.

[37] Smewing J.D., Warburton J.N., Daley T., Copestake P., Ul-Haq N., Sequence stratigraphy of the southern Kirthar Fold Belt and Middle Indus Basin, Pakistan. In: Clift, P. D. Kroon, D. Gaedicke, C. \& Craig, J. (eds) The Tectonic and Climatic Evolution of the Arabian Sea Region. Geological Society, London, Special Publications, 2002, 195, 273-300.

[38] Akhter S., Stratigraphical Map of Lower Indus Basin Pakistan. Geological Survey of Pakistan, 2007

[39] Sheriff R.E., Limitations on resolution of seismic reflections and geologic detail derivable from them. American Association of Petroleum Geologists Memoir, 1977, 26: 3-14.

[40] Badley M.E., Practical Seismic Interpretation. United States, International Human Resources Development Corporation Press, Boston, Massachusetts (MA), Print, 1985

[41] Mitchum Jr R.M., Vail P.R., Sangree J.B., A Stratigraphic interpretation of seismic reflection pattern in depositional sequences, in C.E. Payton, ed., Seismic stratigraphy- Applications to hydrocarbon exploration, American Association of Petroleum Geologists Memoir, 1977, 26: 117-134.

[42] Raza H.A., Ahmed R., Sheikh S.M., et al., Exploration performance in sedimentary zone of Pakistan. Journal of Hydrocarbon Institute of Pakistan, 1989, Records 1: 1-7.

[43] Wandrey C.J., Law B.E., Shah H.A., Sembar Goru/Ghazij composite total petroleum system, Indus and Sulaiman-Kirthar Geologic Provinces, Pakistan and India. United States Geological Survey Bulletin, 2004, 2208.

[44] Schlumberger Educational Services, Log Interpretation Principles/Applications. Houston, Texas, United States of America, 1989, 52.

[45] Glover P., Petrophysics MSc Course Notes. Wire line logging, 2012, 55-246. 
[46] Khan M., Liu Y., Farid A., Aslam K.S., Tectonostratigraphy of the Passive Continental Margin offshore Indus Pakistan, Abstract (T54B-02) presented at 2017 Fall Meeting American Geophysical Union, New Orleans, LA, United States of America, 2017, 1115 Dec.

[47] Calvès G., Clift P.D., Inam A., Anomalous subsidence on the rifted volcanic margin of Pakistan: no influence from Deccan plume. Earth and Planetary Science Letters, 2008, 272: 231239.
[48] Gaedicke C., Prexl A., Schluter H.U., et al. Seismic stratigraphy and correlation of major regional unconformities in the Northern Arabian Sea. Geological Society of London Special Publication, 2002, 195: 25-36.

[49] Rodriguez M., Chamot-Rooke N., Huchon P., Fournier M., et al. Tectonics of the Dalrymple Trough and uplift of the Murray Ridge (NW Indian Ocean). Tectonophysics, 2014, 636: 1-17.

[50] White R.S., Deformation of the Makran continental margin: Geodynamics of Pakistan. Geological Survey of Pakistan, 1979, 295-304. 